\title{
Editorial
}

\section{The Study of Cancer Susceptibility Genes}

\author{
Youri I. Pavlov 1,2,3 (1)
}

1 Eppley Institute for Research in Cancer and Allied Diseases, University of Nebraska Medical Center, Omaha, NE 68198, USA; ypavlov@unmc.edu

2 Departments of Biochemistry and Molecular Biology, Microbiology and Pathology, Genetics Cell Biology and Anatomy, University of Nebraska Medical Center, Omaha, NE 68198, USA

3 Department of Genetics and Biotechnology, Saint-Petersburg State University, 199034 Saint-Petersburg, Russia

Citation: Pavlov, Y.I. The Study of Cancer Susceptibility Genes. Cancers 2021, 13, 2258. https://doi.org/ $10.3390 /$ cancers 13092258

Received: 15 April 2021

Accepted: 21 April 2021

Published: 8 May 2021

Publisher's Note: MDPI stays neutral with regard to jurisdictional claims in published maps and institutional affiliations.

Copyright: (C) 2021 by the author. Licensee MDPI, Basel, Switzerland. This article is an open access article distributed under the terms and conditions of the Creative Commons Attribution (CC BY) license (https:// creativecommons.org/licenses/by/ $4.0 /)$.
"... most complex, new direction for cancer medicine is to integrate our understanding of aberrant genes and pathways to explain the behavior of cancer as a whole, thereby renewing the cycle of knowledge, discovery and therapeutic intervention."- "The Emperor of all Maladies" [1].

Cancer is a disease caused by uncontrolled cell growth driven by genetic changes and the misregulation of genetic information expression. Cancer cells recklessly and selfishly propagate, neglecting the organized developmental scenarios for multicellular organisms, harming the host and eventually themselves. Faults in cell growth control are caused by a plethora of causes: point mutations, copy number variations, chromosome rearrangements, epigenetic alterations, or aberrant forms of essential regulator proteins in the form of amyloids. In few cases, there is a single primary initiation event, but in most cases, a cascade of events causes changes in regulatory networks that result in tumor growth and invasiveness. Defects in the maintenance and expression of hereditary information predispose cells to cancer and influence the outcomes of therapeutic interventions. The current Special Issue of Cancers collects five reviews and 13 experimental papers devoted to the factors playing roles in predisposition to cancer and, in clear documented cases, hereditary forms of cancer. These papers represent a collaborative, international effort revealing the complexity of the problem.

The innovative parallel analysis of cancer-specific DNA sequence variations in genomes and gene expression, affecting not individual genes but molecular pathways falling into four functional groups: signaling, metabolic, cytoskeleton, and DNA repair, revealed that the latter group's genes had the highest mutation enrichment, and upregulation levels [2]. The signaling and cytoskeleton group members were enriched by the genes with many SNVs and experienced the most substantial downregulation of gene expression, alluding to their possible roles as initiators in carcinogenesis. The deregulation of gene expression in angiosarcoma in a TP53-rat model revealed equal numbers of upregulated and downregulated genes [3]. Consistent with the previous study, upregulated genes belong to the DNA repair group and include genes for DNA helicases, chromosome maintenance complexes, recombination, and replication. The Functional Signature Ontology (FUSION) approach of genome-wide, loss-of-function screening is another way to identify critical genes in cancer and find vulnerabilities of tumor cells [4]. A gene expression-based high-throughput screening method allows researchers to identify novel therapeutic targets.

Recent studies on tumor genomes revealed that mutations in replicative DNA polymerase genes caused a predisposition for cancer by increasing genome instability. However, out of three DNA polymerases operating at the replication fork, colon and endometrial cancer-associated mutations (both sporadic and hereditary) predominantly affect the catalytic subunit of polymerase $\mathcal{\varepsilon}$ that participates in leading strand DNA synthesis $[5,6]$, suggesting a unique role that this polymerase plays during replication and human development. It is well established that defects in DNA mismatch repair (Lynch syndrome) predispose to colon and other cancers. The new study found that the condition can also lie 
in the etiology of sarcomas [7]. Fanconi anemia is connected to the defects of machinery dealing with the aberrant replication of damaged DNA with inter-strand DNA crosslinks. The review [8] highlights the importance of Fanconi anemia genes in noncanonical pathways, such as mitochondria homeostasis, inflammation, and virophagy. The primary defects in DNA repair mechanisms in such patients could be exacerbated by an impairment of the cytoprotective pathways, contributing to the disease's multifaceted manifestations.

The hereditary ovarian cancer and, commonly, breast cancer start early and in multiple generations. DNA methylation patterns provide a paradigm for the epigenetic inheritance of cancer susceptibility, with emphasis on co-methylated networks [9]. Multiple paragangliomas and papillary thyroid carcinoma are likely connected to mutations in the DNMT3a gene, responsible for de novo methylation [10]

Changes in developmental programs do not necessarily involve DNA or RNA. The widespread Alzheimer's disease is connected to the accumulation of misfolded polymerized proteins, amyloid $\beta(\mathrm{A} \beta)$ and tau, in brains, and to neuronal degeneration, dementia, and death. Alzheimer's disease patients have a lower incidence of cancer. The study published in this Special Issue revealed that the effect of cancer on the risk of death of Alzheimer's depended on age and the time since cancer diagnosis [11]. Cancer-directed chemotherapy protects against Alzheimer's disease-related death in patients diagnosed with breast cancer. Emerging evidence connects some forms of cancer to the accumulation of critical proteins (e.g., P53) in an amyloid form; therefore, these drugs may affect amyloids.

Several reports documented the roles of defined genes on particular cancer types: CDH1 and CTNNA1 encoding for proteins of the cadherin and catenin families, respectively, and thus cell adhesion, in hereditary diffuse gastric cancer and lobular breast cancer [12]; TNFSF13 (April) and TNSF13B (TACI), genes for ligands of the tumor necrosis factor family in chronic lymphocytic leukemia [13]; and SPON2 (Spondin 2), involved in O-linked glycosylation and ERK signaling in gastric cancer [14]. High levels of CES1 carboxylesterase, responsible for the hydrolysis or transesterification of various xenobiotics' expression, predicted better outcomes for prostate cancer patients [15]. A polymorphism rs6942067 leading to a high transmembrane protein DCBLD1 expression worsens prognosis in human papillomavirus-negative head and neck squamous cell carcinoma [16]. Tumor susceptibility gene 101 (TSG101), encoding for an inactive homolog of ubiquitin-conjugating enzyme, plays a role in normal development and disease [17]. The interaction between two polymorphisms affecting PD-1 and PD-L1 immune checkpoints is connected to renal cancer risk [18].

Two contributions are in the area of genetic counseling. In patients with gastric and pancreatic adenocarcinoma, hereditary syndromes were associated with mutations in mismatch repair, ATM, TP53, CDH1 (cadherin), and BRCA genes [19]. Another study provides evidence for the notion that genetic testing should be done with a broader group of women diagnosed with breast cancer than currently accepted [20].

In summary, this Special Issue of Cancers presents recent progress in the tantalizing task of finding factors contributing to cancer development. When the culprit is identified for a particular cancer type, life-saving strategies of treatment and support may become available, as has happened with specific cancer types, for example, chronic myelogenous leukemia, where treatment with tyrosine kinase inhibitors dramatically improved quality of life and survival. For other types of cancers, progress is being made, but still, there is a long road ahead in the battle of humanity with cancer, given the complexity of the disease and the multiplicity of causing factors.

Conflicts of Interest: The author declares no conflict of interest. 


\section{References}

1. Mukherjee, S. The Emperor of All Maladies: A Biography of Cancer, 1st Scribner hardcover ed; Scribner: New York, NY, USA, 2010; p. 571.

2. Zolotovskaia, M.A.; Tkachev, V.S.; Seryakov, A.P.; Kuzmin, D.V.; Kamashev, D.E.; Sorokin, M.I.; Roumiantsev, S.A.; Buzdin, A.A. Mutation Enrichment and Transcriptomic Activation Signatures of 419 Molecular Pathways in Cancer. Cancers 2020, $12,271$. [CrossRef] [PubMed]

3. Smyczyńska, U.; Strzemecki, D.; Czarnecka, A.M.; Fendler, W.; Fiedorowicz, M.; Wełniak-Kamińska, M.; Guzowska, M.; Synoradzki, K.; Cheda, Ł.; Rogulski, Z.; et al. TP53-Deficient Angiosarcoma Expression Profiling in Rat Model. Cancers 2020, 12, 1525. [CrossRef] [PubMed]

4. $\quad$ Rao, C.; Huisman, D.H.; Vieira, H.M.; Frodyma, D.E.; Neilsen, B.K.; Chakraborty, B.; Hight, S.K.; White, M.A.; Fisher, K.W.; Lewis, R.E. A Gene Expression High-Throughput Screen (GE-HTS) for Coordinated Detection of Functionally Similar Effectors in Cancer. Cancers 2020, 12, 3143. [CrossRef] [PubMed]

5. Pavlov, Y.I.; Zhuk, A.S.; Stepchenkova, E.I. DNA Polymerases at the Eukaryotic Replication Fork Thirty Years after: Connection to Cancer. Cancers 2020, 12, 3489. [CrossRef] [PubMed]

6. Pavlov, Y.I.; Zhuk, A.S.; Stepchenkova, E.I. Correction: Pavlov, Y.I., et al. DNA Polymerases at the Eukaryotic Replication Fork Thirty Years After: Connection to Cancer. Cancers 2020, 12, 3489. Cancers 2021, 13, 969. [CrossRef] [PubMed]

7. de Angelis de Carvalho, N.; Niitsuma, B.N.; Kozak, V.N.; Costa, F.D.a.; de Macedo, M.P.; Kupper, B.E.C.; Silva, M.L.G.; Formiga, M.N.; Volc, S.M.; Aguiar Junior, S.; et al. Clinical and Molecular Assessment of Patients with Lynch Syndrome and Sarcomas Underpinning the Association with MSH2 Germline Pathogenic Variants. Cancers 2020, 12, 1848. [CrossRef] [PubMed]

8. Milletti, G.; Strocchio, L.; Pagliara, D.; Girardi, K.; Carta, R.; Mastronuzzi, A.; Locatelli, F.; Nazio, F. Canonical and Noncanonical Roles of Fanconi Anemia Proteins: Implications in Cancer Predisposition. Cancers 2020, 12, 2684. [CrossRef] [PubMed]

9. Reid, B.M.; Fridley, B.L. DNA Methylation in Ovarian Cancer Susceptibility. Cancers 2021, 13, 108. [CrossRef] [PubMed]

10. Mellid, S.; Coloma, J.; Calsina, B.; Monteagudo, M.; Roldán-Romero, J.M.; Santos, M.; Leandro-García, L.J.; Lanillos, J.; MartínezMontes, Á.M.; Rodríguez-Antona, C.; et al. Novel DNMT3A Germline Variant in a Patient with Multiple Paragangliomas and Papillary Thyroid Carcinoma. Cancers 2020, 12, 3304. [CrossRef] [PubMed]

11. Mezencev, R.; Chernoff, Y.O. Risk of Alzheimer's Disease in Cancer Patients: Analysis of Mortality Data from the US SEER Population-Based Registries. Cancers 2020, 12, 796. [CrossRef] [PubMed]

12. Marwitz, T.; Hüneburg, R.; Spier, I.; Lau, J.-F.; Kristiansen, G.; Lingohr, P.; Kalff, J.C.; Aretz, S.; Nattermann, J.; Strassburg, C.P. Hereditary Diffuse Gastric Cancer: A Comparative Cohort Study According to Pathogenic Variant Status. Cancers 2020, $12,3726$. [CrossRef] [PubMed]

13. Jasek, M.; Bojarska-Junak, A.; Sobczyński, M.; Wagner, M.; Chocholska, S.; Roliński, J.; Wołowiec, D.; Karabon, L. Association of Common Variants of TNFSF13 and TNFRSF13B Genes with CLL Risk and Clinical Picture, as Well as Expression of Their Products-APRIL and TACI Molecules. Cancers 2020, 12, 2873. [CrossRef] [PubMed]

14. Kang, H.-G.; Kim, W.-J.; Noh, M.-G.; Chun, K.-H.; Kim, S.-J. SPON2 Is Upregulated through Notch Signaling Pathway and Promotes Tumor Progression in Gastric Cancer. Cancers 2020, 12, 1439. [CrossRef] [PubMed]

15. Ke, C.-C.; Chen, L.-C.; Yu, C.-C.; Cheng, W.-C.; Huang, C.-Y.; Lin, V.C.; Lu, T.-L.; Huang, S.-P.; Bao, B.-Y. Genetic Analysis Reveals a Significant Contribution of CES1 to Prostate Cancer Progression in Taiwanese Men. Cancers 2020, 12, 1346. [CrossRef] [PubMed]

16. Cardin, G.B.; Bernard, M.; Bahig, H.; Nguyen-Tan, P.F.; Ballivy, O.; Filion, E.; Soulieres, D.; Philouze, P.; Ayad, T.; Guertin, L.; et al. Single Nucleotide Polymorphism rs6942067 Is a Risk Factor in Young and in Non-Smoking Patients with HPV Negative Head and Neck Squamous Cell Carcinoma. Cancers 2020, 12, 55. [CrossRef] [PubMed]

17. Ferraiuolo, R.-M.; Manthey, K.C.; Stanton, M.J.; Triplett, A.A.; Wagner, K.-U. The Multifaceted Roles of the Tumor Susceptibility Gene 101 (TSG101) in Normal Development and Disease. Cancers 2020, 12, 450. [CrossRef] [PubMed]

18. Wagner, M.; Tupikowski, K.; Jasek, M.; Tomkiewicz, A.; Witkowicz, A.; Ptaszkowski, K.; Karpinski, P.; Zdrojowy, R.; Halon, A.; Karabon, L. SNP-SNP Interaction in Genes Encoding PD-1/PD-L1 Axis as a Potential Risk Factor for Clear Cell Renal Cell Carcinoma. Cancers 2020, 12, 3521. [CrossRef] [PubMed]

19. Llach, J.; Moreno, L.; Sánchez, A.; Herrera-Pariente, C.; Ocaña, T.; Cuatrecasas, M.; Rivero-Sánchez, L.; Moreira, R.; Díaz, M.; Jung, G.; et al. Genetic Counseling for Hereditary Gastric and Pancreatic Cancer in High-Risk Gastrointestinal Cancer Clinics: An Effective Strategy. Cancers 2020, 12, 2386. [CrossRef] [PubMed]

20. Rummel, S.K.; Lovejoy, L.A.; Turner, C.E.; Shriver, C.D.; Ellsworth, R.E. Should Genetic Testing for Cancer Predisposition Be Standard-of-Care for Women with Invasive Breast Cancer? The Murtha Cancer Center Experience. Cancers 2020, $12,234$. [CrossRef] [PubMed] 